\title{
Cholecystokinin-1 receptor antagonists: 5-hydroxy-5-aryl-pyrrol-2-ones as anticancer $\operatorname{agents}^{\dagger}$
}

E. Lattmann, ${ }^{\text {a }}$ S. T. Russell, ${ }^{\mathrm{a}}$ C. H. Schwalbe, ${ }^{\mathrm{a}}$ A. Shortt, ${ }^{\mathrm{a}}$

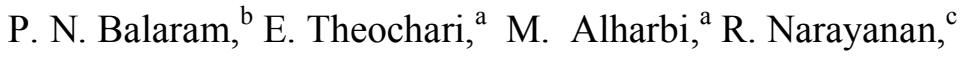
and P. Lattmann ${ }^{\mathrm{b}}$

a. School of Life and Health Sciences, Aston University, Aston Triangle, Birmingham B4 7ET, England.

b. PNB Vesper Life Science PVT, Cochin, Kerala, India.

c. Department of Medicine, University of Tennessee Health Science Center, Memphis, TN, USA.

${ }^{\dagger}$ The authors declare no competing interests.

\begin{abstract}
A new class of 5-arylated 5-hydroxypyrrolones was derived from mucochloric acid in 2 synthetic steps and the chemical structure was confirmed additionally by $\mathrm{x}$-ray analysis. Using a radiolabelled binding assay, potent $\mathrm{CCK}_{1}$ selective ligands were identified $\left(\mathrm{CCK}_{1}\right.$ : $12 \mathrm{nM}$ ) and the antagonism was confirmed by using isolated tissue preparations. A series of isobutyl derivatives displayed unsurmountable CCK antagonistic properties and in vitro excellent inhibition of proliferation was obtained in cholecystokinin related cancer cell lines in the nanomolar range. Finally, using xenograft studies in nude mice, two selected pyrrolone derivatives, $\mathrm{X}=\mathrm{H}$ and $\mathrm{X}=\mathrm{F}$ a fluorinated analogue ( PNB-028), showed a strong inhibition of tumour growth in a chemo-resistant colon cancer- (MAC 16) and a human pancreatic cell line (MIAPACA) at $50 \mathrm{mg} / \mathrm{kg}$ by oral administration.
\end{abstract}

\section{Introduction}

Cholecystokinin (CCK) acts as a neuromodulator in the brain and as a gut hormone in the gastrointestinal tract. CCK-ligands, agonists as well as antagonists, ${ }^{1}$ have been 
extensively investigated as potential drug molecules. ${ }^{2}$ Originally, cholecystokinin was discovered to cause contractions of the gallbladder, it was then rediscovered as pancreozymin, triggering the release of pancreatic enzymes and then, it was confirmed that both peptides are identical. ${ }^{3}$

Gastin, closely related to cholecystokinin, triggers the release of gastric acid and in vitro in cell lines, gastric cancer is gastrin dependant. ${ }^{4}$ Cholecystokinin does cause proliferation in colon- and pancreatic cancer cell lines and therefore, CCK-antagonists were studied as growth factor inhibitors in certain forms of cancer. ${ }^{5}$ They were evaluated as anxiolytics, ${ }^{6}$ in the treatment of schizophrenia, ${ }^{7}$ satiety ${ }^{8}$ and reviewed as anxiolytics. ${ }^{9}$ These properties may be beneficial in cancer patients in addition to their anti-neoplastic activity. 
<smiles>CC(C)C[C@H]1N[C@H]2N(C1=O)c1ccccc1C2(O)C[C@@H]1NC(=O)c2ccccc2-n2c1nc1ccccc1c2=O</smiles>

Asperlicin<smiles>Cc1cccc(NC(=O)N[C@@H]2N=C(c3ccccc3)c3ccccc3N(C)C2=O)c1</smiles>

L-365,260<smiles>CCCN(CCC)C(=O)C(CCC(=O)O[Na])NC(=O)c1ccccc1</smiles>

Proglumide<smiles>CN1C(=O)C(NC(=O)c2cc3ccccc3[nH]2)N=C(c2ccccc2)c2ccccc21</smiles>

Devazepide

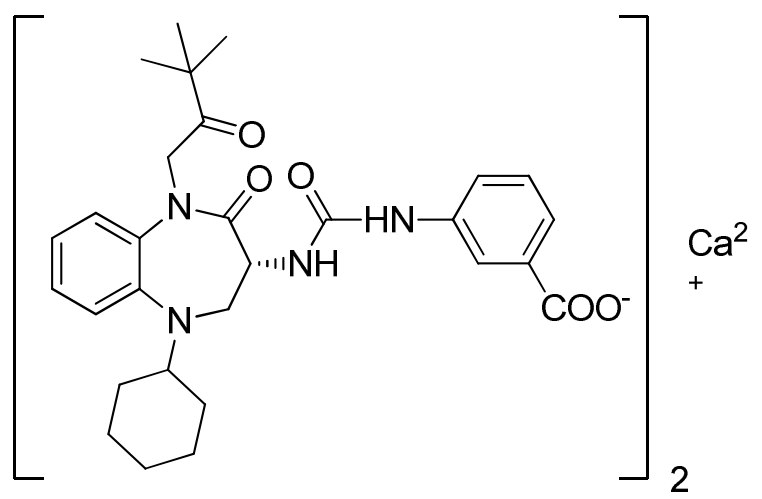

Z-360<smiles>CCCCCN(CCCCC)C(=O)C(CCC(=O)O[Na])NC(=O)c1ccc(Cl)c(Cl)c1</smiles>

Lorglumide

Fig.1 Drug design from Asperlicin, via Devazepide, a $\mathrm{CCK}_{1}$ selective antagonist, a $\mathrm{CCK}_{2}$ selective antagonist, L-365,260 towards Z-360, a potent and water soluble $\mathrm{CCK}_{2}$ antagonist. 
Asperlicin (Fig. 1) was the first non-peptidal CCK antagonist lead structure from nature and analogues thereof, were studies as CCK ligands. ${ }^{10}$ Simplification of the lead structure by Merck led to Devazepide, ${ }^{11}$ a potent $\mathrm{CCK}_{1}$ selective cholecystokinin antagonist, containing a 1,4-benzodiazepine template and an indole moiety. Devazepide was tested clinically in 18 patients with advanced cancer ${ }^{12}$ without escalating doses and failed to show significant effects due to its poor pharmacokinetic properties.

The indolyl amide of devazepide was replaced by a urea linkage and Merck's L365,260 resulted in a $\mathrm{CCK}_{2}$ selective antagonist. Further subsequent SAR optimisation led to Zeria's improved Z-360, ${ }^{13}$ in which the $\mathrm{N}$-alkyl side chain, the 5- position (cyclohexyl) was optimised for potency and a meta-carboxylic acid on the aryl urea linkage was introduced to enhance water solubility of the $\mathrm{CCK}_{2}$ antagonists (Fig. 1). $\mathrm{Z}-360$ is a $\mathrm{CCK}_{2}$-gastrin receptor antagonist and progressed into phase 2 trial with pancreatic cancer. ${ }^{14}$

Lorglumide is 25 times more potent in blocking the cholecystokinin induced contractions of the gallbladder than proglumide, but the activity to block pancreatic amylase secretion is only better by factor $2,{ }^{15}$ indicating a heterogeneity of the $\mathrm{CCK}_{1}$ receptor.

Proglumide with $\mathrm{mM}$ activity is too non-potent, requiring multi gramme quantities for potential cancer treatment.

In our search for new CCK ligands, in which the 1,4-benzodiazepine structure ${ }^{16}$ was replaced by an achiral diphenyl pyrazolone template, novel CCK antagonists with an indole carboxylic acid ${ }^{17}$ and a phenyl urea moiety ${ }^{18}$ were found and optimised with excellent animal data on anxiety and depression. ${ }^{19}$ The 1,4-benzodiazepine template of devazepide was varied by a combinatorial solid phase synthesis ${ }^{20}$ and was optimised in terms of CCK binding affinity. ${ }^{21}$

Again, having realized the poor pharmacokinetic properties of these agents, a search for a completely novel, smaller template ${ }^{22}$ with a molecular weight $<350$, a log p about 3 and a polar surface area for membrane penetration of less that $100 \mathrm{~A}$, with no urea linkage was initiated (Fig. 2).

Here, we identified within a novel chemical class, potent irreversible cholecystokinin antagonists, which translated in vitro and in vivo efficiency into new chemical entities 
(NCE) for the treatment of colon and pancreatic cancer. The pyrrolone 10 entered preclinical development (PNB-028) and showed excellent metabolic stability, a very high bioavailability (98\%) and a half-life of $3.5 \mathrm{~h}$ in rats.

$\mathrm{CCK}_{2}$

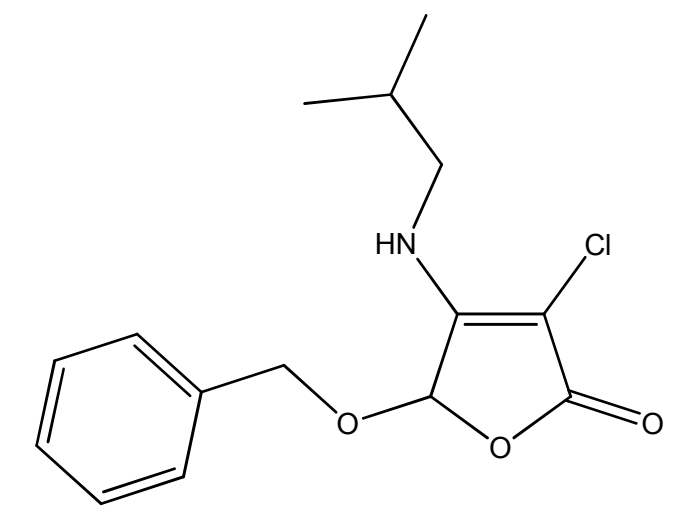

5-(benzyloxy)-3-chloro-4-(isobutylamino)furan$2(5 H)$-one

Lactone
$\mathrm{CCK}_{1}$ antagonists

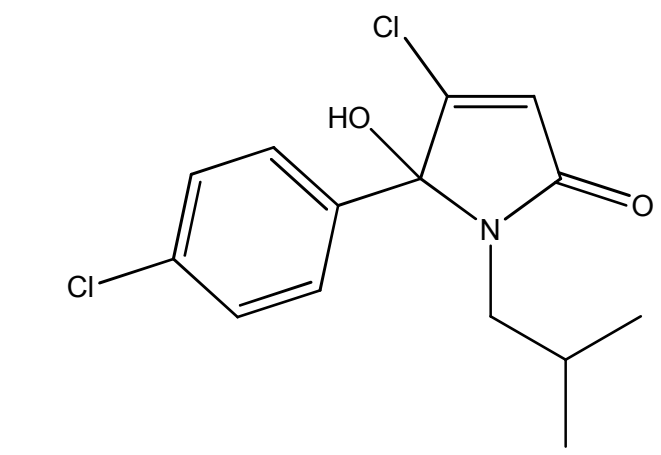

4-chloro-5-(4-chlorophenyl)-5-hydroxy-1-isobutyl$1 H$-pyrrol-2(5H)-one

Lactame - template

Fig. 2 From 4-amino-(2H)- furanones to novel hydroxyl-pyrrolones, a conversion of gastrin antagonists into cholecystokinin antagonists.

\section{Results and discussion}

\section{Chemistry}

The arylated dichloro-2(5H)-furanones (Lactone A, B, C) were synthesised from mucochloric acid (Scheme 1), which is available from furfural under oxidising conditions with hydrochloric acid. Theses arylated intermediates were chemically optimised by us previously and evaluated as anticancer agents. ${ }^{23}$

Under mild conditions, using ether as solvent, the arylated furanones A, B, C were reacted with a range of amines, required for SAR optimisation towards the $\mathrm{CCK}_{1}$ 
receptor, into the desired arylated pyrrolones 1-16 in a 1 step synthesis in high yields (Scheme 1).
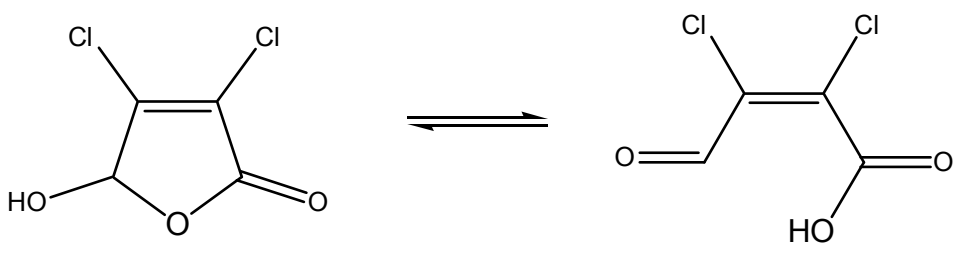

Mucochloric acid
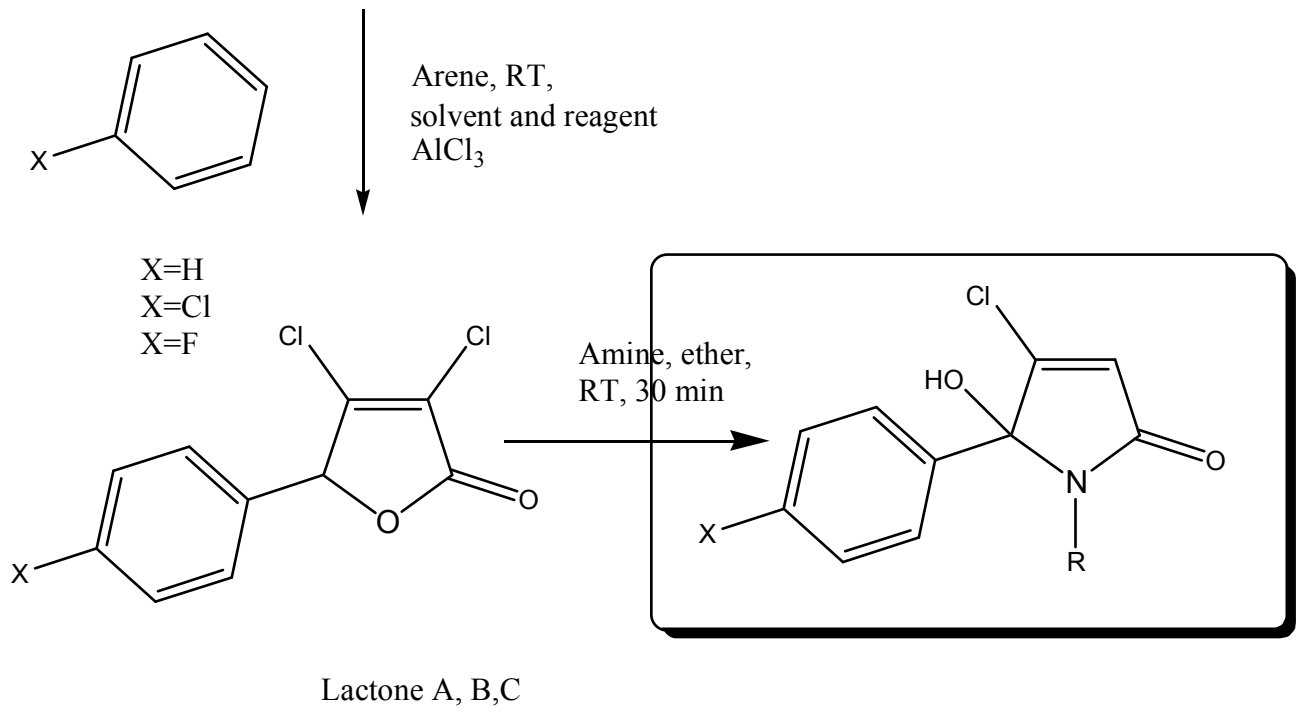

Lactame 1-16

Scheme 1 Synthesis of arylated lactams 1-16.

The experimental details are described in ESI under the section "materials and methods" and no acyclic ketone, the ring opened form of the hydroxyl-pyrrolone, was observed. On a small scale purification was performed by column chromatography and on a multigramme scale, the isobytyl series 9-11 was purified by recrystallisation with methanol.

As the gold standard of structure characterisation, the x-ray structure of pyrrolone 9 was determined. Both stereoisomers are displayed in Fig. 3. The molecule is not present in a keto form and fully occurred in the 5-membered ring form, as a hydroxyl - pyrrolone. 

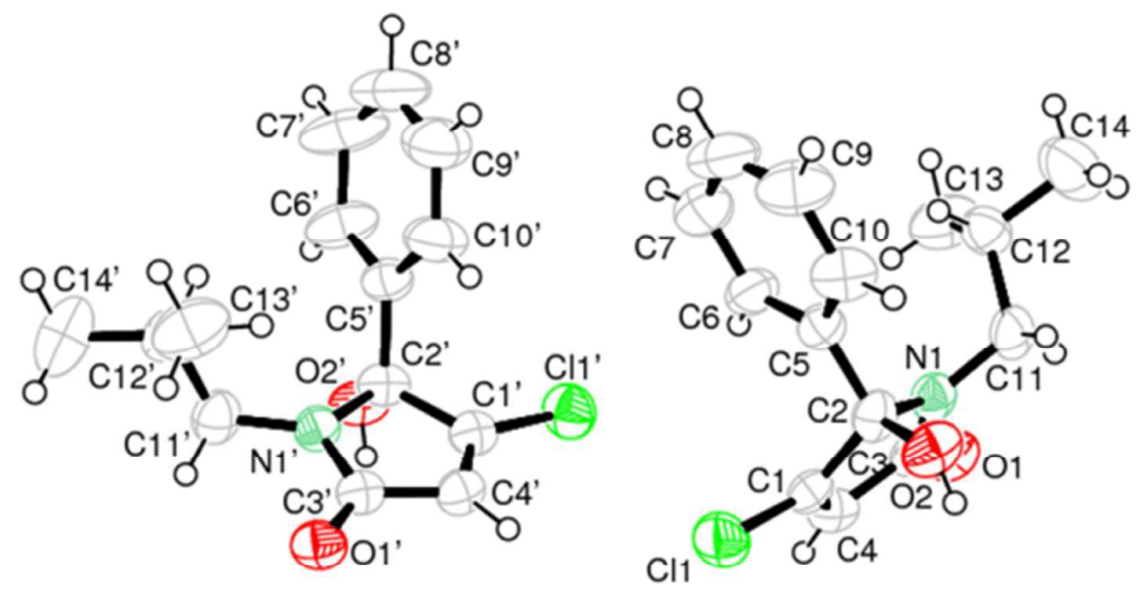

Fig. 3 X-ray structure of 4-Chloro-5-hydroxy-1-isobutyl-5-phenyl-1,5-dihydro-pyrrol2-one, the lactame 9 recrystallised from methanol.

\section{SAR optimisation}

The initial step of evaluation was to screen for potent binding affinity and to identify a $\mathrm{CCK}_{1}$ selective ligand for the treatment of cholecystokinin related conditions.

Using radiolabel iodinated cholecystokinin, inhibition of binding was determined for all test molecules and the $\mathrm{IC}_{50}$ are outlined in Table 1.

$\mathrm{N}$-methyl group, present in lactame 1, showed no binding affinity and an increase in the length of the side chain resulted in micromolar binding for the iso-propyl group, as seen in lactame 3 and 4.

Ring closure on the N-substituent, from isopropyl to cyclo-propyl resulted in a loss of activity (lactame 5,6) and ring enlargement from a 3- membered to a 5- membered ring system resulted in no significant increase of binding affinity.

The change from a propyl into a butyl group resulted in a manifold increase of activity and the best substituent was found isobutyl, as shown in Figure 4 for the iso-butyl series 9-11. The introduction of a halogen atom resulted in an increase of binding 
affinity, possibly due to enhanced lipophilicity and the best overall molecule is pyrrolone 11 with an $\mathrm{IC}_{50}$ about $8 \mathrm{nM}$. The t-butyl analogue 12 was formed in very low yields, same as a pentyl analogue (not included).

Table 1 CCK binding affinity using radioligands with cortex and pancreatic membranes. $\mathrm{IC}_{50}$ is presented in micromolar; $\mathrm{N}=3$.

\begin{tabular}{|c|c|c|c|c|}
\hline Pyrrolone & $\mathrm{X}=$ & $\mathrm{R}=$ & $\begin{array}{l}\text { CCK-A } \\
{[\mu \mathrm{M}]}\end{array}$ & $\begin{array}{l}\text { CCK-B } \\
{[\mu \mathrm{M}]}\end{array}$ \\
\hline 1 & $\mathrm{H}$ & $\mathrm{Me}$ & $2.5 \pm 0.2$ & $>10$ \\
\hline 2 & $\mathrm{Cl}$ & $\mathrm{Me}$ & $2.0 \pm 0.2$ & $>10$ \\
\hline 3 & $\mathrm{H}$ & $\mathrm{I}-\mathrm{Pr}$ & $0.2 \pm 0.02$ & $0.9 \pm 0.03$ \\
\hline 4 & $\mathrm{Cl}$ & I-Pr & $0.3 \pm 0.04$ & $3.7 \pm 0.4$ \\
\hline 5 & $\mathrm{H}$ & Cyclopropyl & $7.5 \pm 0.3$ & $>10$ \\
\hline 6 & $\mathrm{Cl}$ & Cyclopropyl & $4 \pm 0.3$ & $>10$ \\
\hline 7 & $\mathrm{H}$ & Cyclopentyl & $0.36 \pm 0.3$ & $0.84 \pm 0.4$ \\
\hline 8 & $\mathrm{Cl}$ & Cyclopentyl & $2.5 \pm 0.2$ & 10 \\
\hline 9 & $\mathrm{H}$ & Isobutyl & $0.020 \pm 0.01$ & $1.2 \pm 0.3$ \\
\hline 10 & $\mathrm{~F}$ & Isobutyl & $0.012 \pm 0.01$ & $0.75 \pm 0.2$ \\
\hline 11 & $\mathrm{Cl}$ & Isobutyl & $0.008 \pm 0.01$ & $0.4 \pm 0.2$ \\
\hline 12 & $\mathrm{H}$ & t-butyl & $0.12 \pm 0.22$ & $0.9 \pm 0.03$ \\
\hline 13 & $\mathrm{H}$ & Hexyl & $4.5 \pm 0.3$ & $>10$ \\
\hline 14 & $\mathrm{Cl}$ & Hexyl & $3.6 \pm 0.3$ & $>10$ \\
\hline 15 & $\mathrm{H}$ & Cyclohexyl & $>10$ & $>10$ \\
\hline 16 & $\mathrm{H}$ & $\mathrm{Ph}$ & $>10$ & $>10$ \\
\hline 17 & $\mathrm{H}$ & $\mathrm{Bz}$ & $0.80 \pm 0.04$ & $0.022 \pm 0.002$ \\
\hline Lorglumide & - & - & $0.17 \pm 0.01$ & $>10$ \\
\hline
\end{tabular}

The n-hexyl lactame 13, 14 clearly lost activity and the same was observed for the cyclohexylderivative 15 . Lactames, such as pyrrolone 16, containing an aromatic ring directly connected to the $\mathrm{N}$-position showed a micromolar activity $>10 \mu \mathrm{M}$. Most 
interestingly, the introduction of a N-benzyl substituent to the pyrrolone template, instead of an alkyl group, resulted in the mixed CCK-ligand, pyrrolone 17 (Fig. 4). This is a new lead structure towards $\mathrm{CCK}_{2}$ selective antagonists and a full lead optimisation is in high progress.

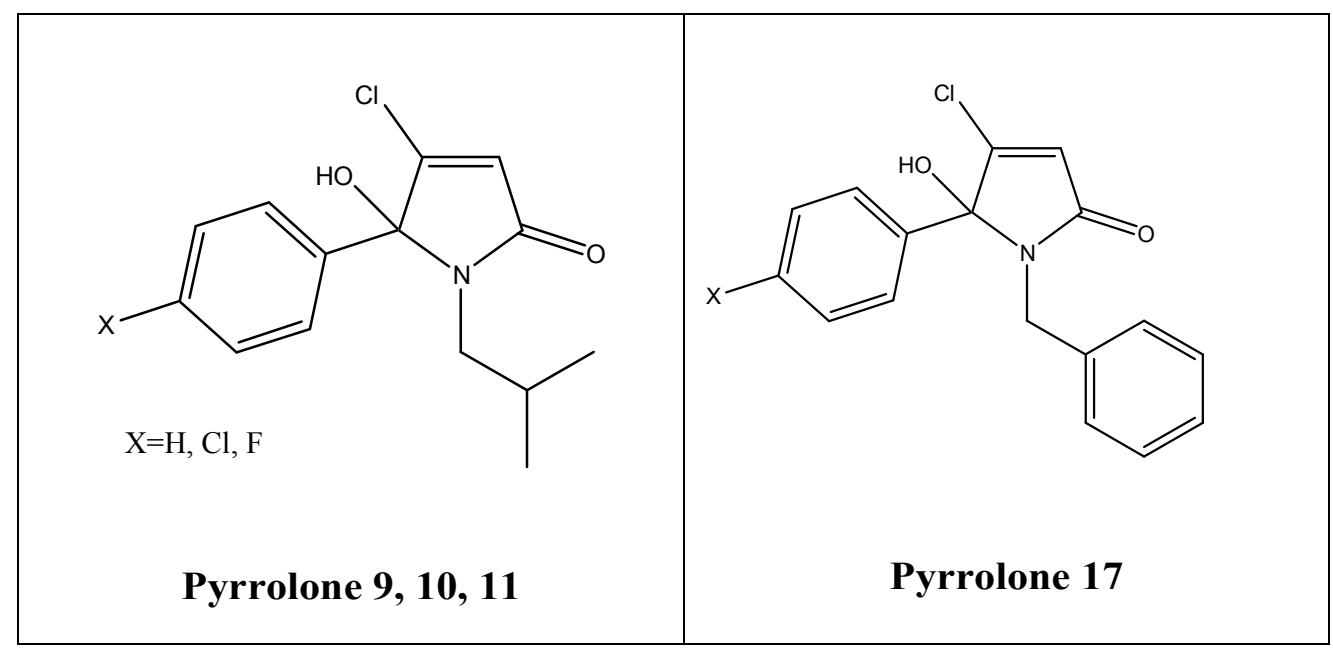

Fig. 4 From a $\mathrm{CCK}_{1}$ antagonist towards a $\mathrm{CCK}_{2}$ lead structure. Overview of selected pyrrolones (lactames).

Generally, within the isobutyl series the halogen atom on the 5-arylated ring enhanced the binding affinity. The $\mathrm{IC}_{50}$ was enhanced from $20 \mathrm{nM}$ for pyrrolone 9 , towards the $10 \mathrm{nM}$ range for the halogenated entities. Most importantly the metabolism, such as an expected hydroxylation in the para-phenyl position, would be blocked, resulting in agents with improved pharmacokinetic properties.

Molecular modelling studies were performed to rationalise drug receptor interactions of the pyrrolone 11 with the $\mathrm{CCK}_{1}$ receptor.

The isobutyl group of the ligand interacted with a hydrophobic cave of the receptor, centred at Ala-14. The carbonyl group in the 2- position bond via hydrogen binding towards the CCK receptor with Arg-9 and the N- atom of the lactame interacted with Glu-17. The 5-hydroxyl group of the lactame ligand displayed interactions with of Asn-6, which are outlined in Fig. 5. 


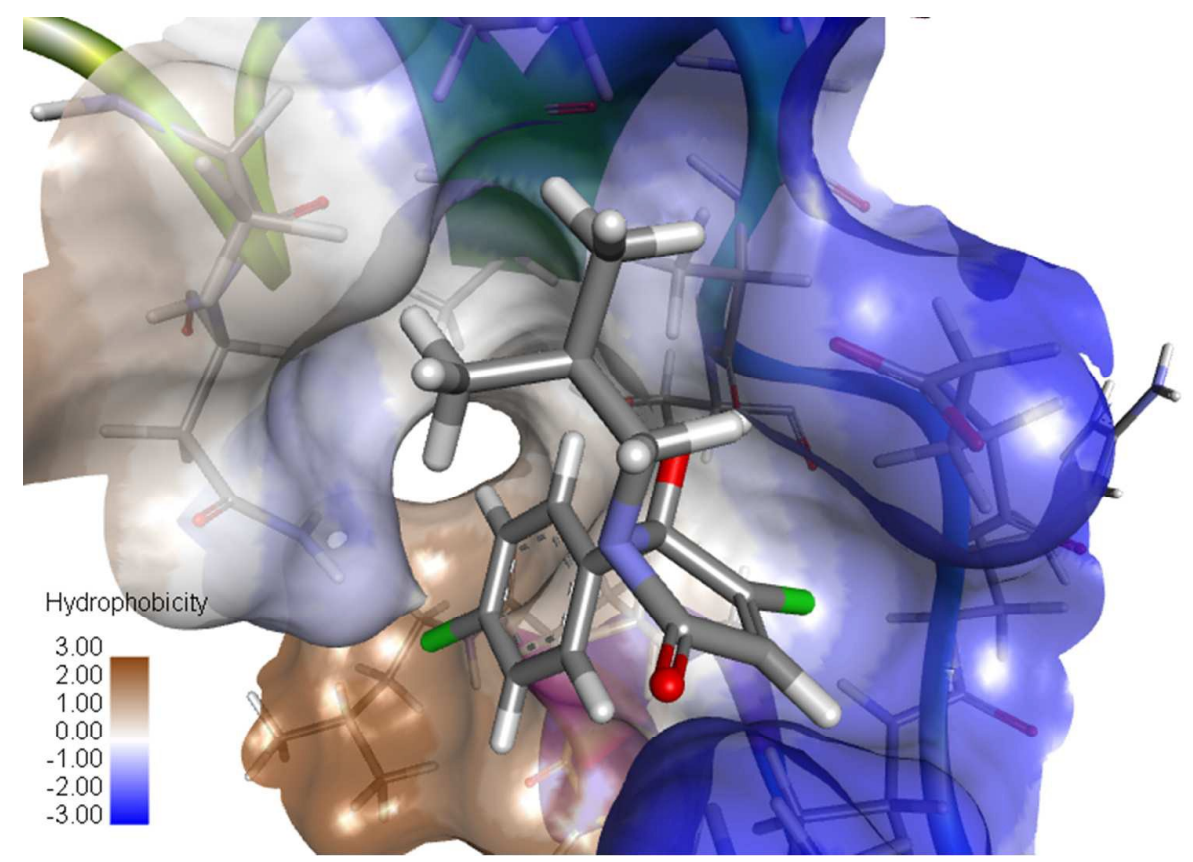

Fig. 5 Drug receptor interactions of lactame 11 with the $\mathrm{CCK}_{1}$ receptor.

The phenyl group has no interaction with tryptophan or phenylalanine and Pi - alkyl interactions of the chloro-phenyl group with Leu-29 and Ile-28 explain the small increase in specific binding. The ligand acted as irreversible inhibitor in vitro and the $3^{\text {rd }}$ extracellular loop of the $\mathrm{CCK}_{1}$ receptor with the natural ligand $\mathrm{CCK}_{8 \mathrm{~s}}$ binding site, was selected to initiate modelling. It was assumed that irreversible, possibly covalent interaction with this loop of the receptor may deform the site and explain the superiority of the antineoplastic activity of this class of agents compared with competitive inhibitors.

\section{Pharmacology}

Opiate agonists, such as morphine and CCK antagonists, such as lorglumide and devazepide reduced electrically induced contractions on the GPI. From the radioligand binding assay the iso-butyl-pyrrolones were identified as the most potent ligands, and the classical isolated tissue preparation served as initial functional assay, confirming the antagonistic properties of these ligands. 


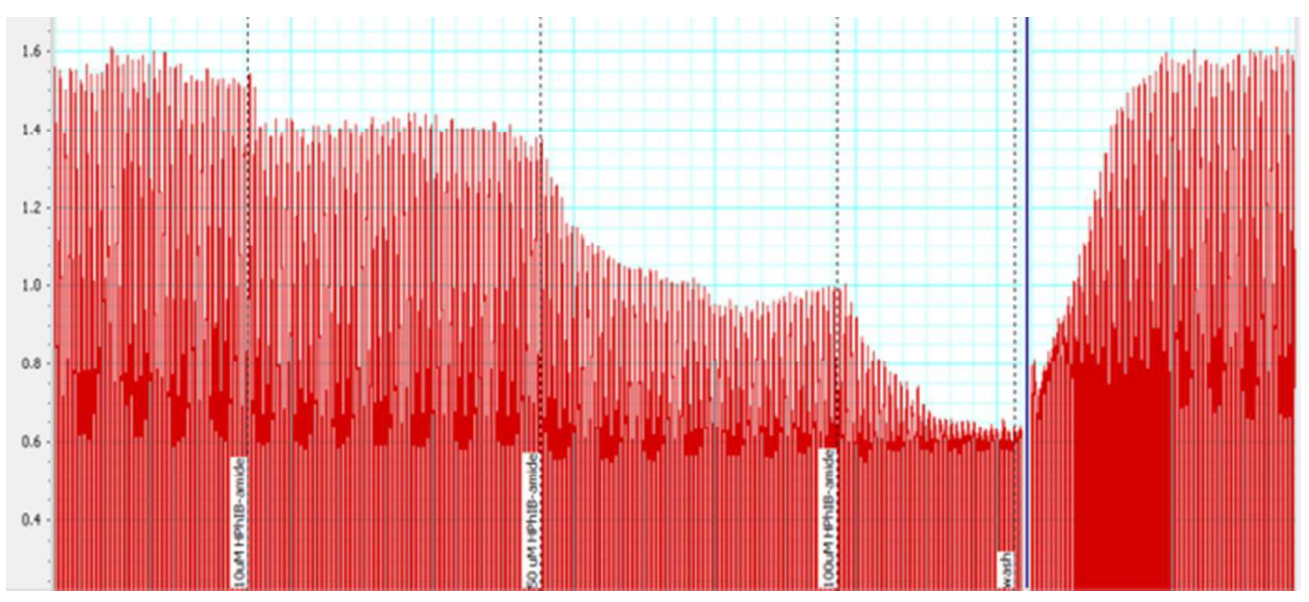

Fig. 6 The inhibitory effect of $0.1,0.5$ and $1.0 \mu \mathrm{M}$ of pyrrolone 11 on electrically stimulated rat duodenum tissue contractions.

Using the isolated rat duodenum preparation, a stable amplitude was generated and a reduction of this amplitude was observed dose dependently for the isobutyl series, which is outlined in figure 6 for the pyrrolone 11. This assay represents a fast and efficient way to screen for CCK antagonists using classical isolated tissue preparations.

Cholecystokinin, $\mathrm{CCK}_{8 \mathrm{~s}}$, induced contractions of the guinea pig gall bladder and this second tissue based assay was applied to reconfirm with this standard preparation the antagonistic properties of the potent CCK ligands.

CCK-8s induced contractions of the gall bladder and these contractions were reduced dose dependently, which is outlined for pyrrolone 11 in fig. 7. The concentration response curve was calculated based on the percentage response to $10^{-5} \mathrm{M}$ ACh for a better comparison. Increased concentrations of the antagonist, pyrrolone $11=\mathrm{ClIBA}$ were added to the bath cumulatively and a shift of the curve to the right was observed. The function of the halogen atom is to enhance binding affinity/ increase lipophilicity and most importantly, to block metabolism of the molecules in the para - phenyl position. 


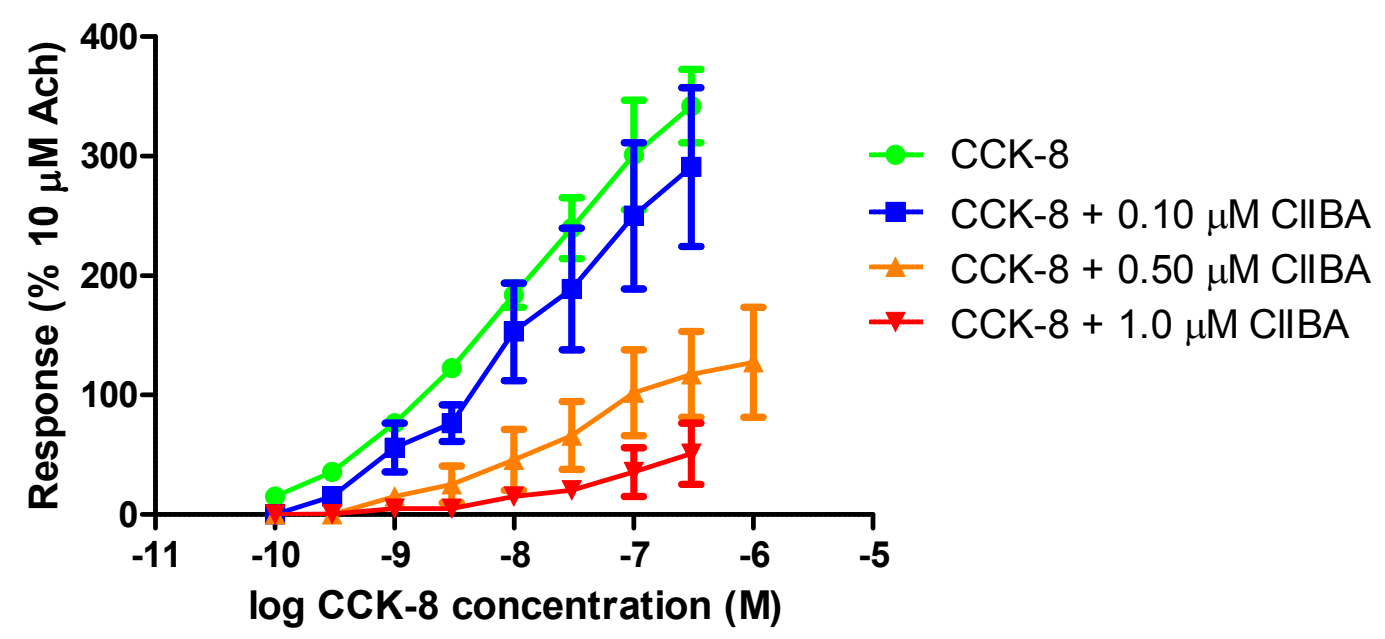

Fig. 7 Mean cumulative concentration-response curve for CCK-8s in the absence and presence of $0.1,0.5$ and $1.0 \mu \mathrm{M}$ CIIBA/pyrrolone 11 determined for the isolated guinea pig gallbladder (Internal standard: ACh $10 \mu \mathrm{M}=100 \%$ contraction).

It appeared that the effect of the antagonist in the gallbladder assay is insurmountable and an irreversible inhibitor is ideal for the development of antineoplastic agents. Reactive chlorine in the 4- position may be suitable for covalent drug receptor interactions, explaining an irreversible antagonism for the isobutyl- pyrrolone series.

The antineoplastic properties of selected NCE and standard CCK antagonists, such as L-365,260 $\left(\mathrm{CCK}_{2}\right)$, devazepide and lorglumide $\left(\mathrm{CCK}_{1}\right)$ was subsequently investigated, using a range of CCK associated cancer cell lines.

\section{In vitro cancer cell based testing}

CCK antagonists are associated with an array of therapeutic applications, but the focus of our research programme was to provide a non-toxic orally available CCK antagonist for the treatment of cancers.

\section{In vitro tests - Cytotoxicity assays}

In vitro tests were originally performed using a cell count assay, as the aim was to inhibit proliferation and not to optimise cytotoxicity, but the results were identical in 
the methylthiazolyltetrazolium (MTT) assay, possible due to induced apoptosis. It was screened for an inhibitor of viability in certain CCK related cancers cell lines using the MTT assay.

MIA PACA: Miapaca is a human pancreatic carcinoma cell line and selected data are outlined in Table 2. Pyrrolone 9 was found 20 times better in terms of $\mathrm{IC}_{50}$ concentrations than lorglumide. Devazepide, which gave an $\mathrm{IC}_{50}$ about $1 \mu \mathrm{M}$ showed agonistic activity (unpublished results). Lorglumide, a $\mathrm{CCK}_{1}$ antagonist, was acting on the gallbladder $\mathrm{CCK}_{1}$ receptor and not the pancreatic CCK receptor. None of the known CCK antagonists, devazepide or lorglumide proved to be clinical useful, which is in line with our results.

AGS: AGS is a human stomach cancer cell line and was selected to screen for anticancer activity within the entire GI system including the stomach. The stomach contains $\mathrm{CCK}_{2}$ /gastrin receptors and pyrrolone 17 occurred some $\mathrm{CCK}_{2}$ activity. $\mathrm{CCK}_{2}$ is gastrin and it is no surprise that a more $\mathrm{CCK}_{2}$ antagonist, (or the combination $\left.\mathrm{CCK}_{1} / \mathrm{CCK}_{2}\right)$ is working best on this cell line.

PANC: The PANC cell line is a human pancreatic cell line. Pyrrolone 9 is many times better than devazepide / lorglumide on this selected pancreatic cell line. Cancer treatment is combination therapy, even for hormone dependent cancers. For this pancreatic cell line the synergistic effects of MK-329 = devazepide in conjunction with cisplatin were reported ${ }^{24}$ and studies to investigate pyrrolone 10 , which is now PNB-028 with cis - platin and 5-FU are ongoing.

Overall, pyrrolone 9, 10,11 were not significantly different from each other and the parent pyrrol 9 and the halogenate fluorinated pyrrolone 10 were tested subsequently in vivo in xenograft models. In vitro in cell based assays they were found of equal selective toxicity towards 2 human pancreatic and 2 colon cancer cell lines. The cytotoxicity results for CCK related cell lines are outlined in table 2 with lorglumide and devazepide as $\mathrm{CCK}_{1}$ standard and L-365,260 as $\mathrm{CCK}_{2}$ standard.

U373MG: The anticancer activity of the agents is not limited to GI cancers. The cytotoxicity of the glioblastoma cell line U373MG, a brain cancer cell line, was determined for a small series of test compounds including for Merck's $\mathrm{CCK}_{2}$ 
antagonist L-365,260. The $\mathrm{CCK}_{1}$ antagonist, pyrrolone 9 and L-365,260 were found of high nanomolar activity. The mixed CCK antagonist, pyrrolone 16 showed low nanomolar activity and a programme for the development of mixed CCK antagonists on this lead structure was initiated and the results will be communicated in a second publication.

Table 2 Cytotoxicity assay, $\mathrm{IC}_{50}$ of selected examples against a variety of GI and brain cell lines. $\mathrm{IC}_{50}$ values are based on inhibition of viability in the MTT assay in various cell lines.

\begin{tabular}{|l|l|l|l|l|l|l|}
\hline $\begin{array}{l}\mathrm{IC}_{50} \\
{[\mathrm{nM}]}\end{array}$ & MIA & AGS & PANC & U373MG & MAC13 & MAC16 \\
\hline L-365,260 & $>5000$ & $675 \pm 54$ & $>1000$ & $541 \pm 87$ & $>5000$ & $>5000$ \\
\hline Devazepide & 1200 & $>5000$ & $480 \pm 32$ & $>5000$ & 1100 & 1000 \\
\hline Lorglumide & $425 \pm 23$ & $289 \pm 14$ & $316 \pm 21$ & $>5000$ & $421 \pm 11$ & $861 \pm 22$ \\
\hline Pyrrolone 9 & $15 \pm 4$ & $262 \pm 18$ & $27 \pm 9$ & $765 \pm 29$ & $536 \pm 32$ & $96 \pm 25$ \\
\hline Pyrrolone 10 & $11 \pm 4$ & $222 \pm 16$ & $18 \pm 6$ & $665 \pm 28$ & $508 \pm 35$ & $76 \pm 20$ \\
\hline Pyrrolone 11 & $13 \pm 4$ & $242 \pm 18$ & $22 \pm 9$ & $475 \pm 25$ & $526 \pm 34$ & $86 \pm 23$ \\
\hline Pyrrolone 17 & $230 \pm 11$ & $53 \pm 4$ & $674 \pm 33$ & $23 \pm 3$ & $>1000$ & $>1000$ \\
\hline
\end{tabular}

A mixed antagonist may work best for treating brain cancers, as mengionomas express $\mathrm{CCK}_{1}$ receptors and astrocytomas $\mathrm{CCK}_{2}$ receptors. ${ }^{25}$ A human glioma cell line, U-87 responded to $\mathrm{CCK}_{2}$ antagonists, ${ }^{26}$ unknown uncharacterised primary tumour cell lines only to mixed CCK antagonists (Lattmann \& Buchfelder unpublished). 
The antineoplastic effect, mediated by blocking CCK receptors, which are expressed in parts of the GI system, correlated well in vitro cell culture and isolated tissue preparations.

MAC 16: MAC 13 and MAC 16 cancers are derived from the colon of the mouse and MAC 16 is of particular interest, as it is resistant to alkylating agents.

For pyrrolone 9, an $\mathrm{IC}_{50}$ about $100 \mathrm{nM}$ was determined for the MAC 16 cell line and the fluorinated analogue 10 was slightly more potent. Most interestingly, no other CCK antagonist, such as L-365,260, devazepide or lorglumide was found active for this cell line, which is, when transplanted into mice lethal within weeks. Therefore, it may be concluded, that the unsurmountable irreversible properties of the antagonists are key to colon cancer.

Subsequently, this tumour was studied initially in mice to analyse, if the in vitro results can be translated into relevant anti-tumour activity.

\section{Xenograft studies in nude mice}

\section{MAC 16 tumour xenograft study}

MAC 16 tumours developed quickly within 10 days after implantation and grew robustly. Once the tumours reached $100 \mathrm{~mm}^{3}$, (Fig. 8) the animals were divided into the various treatment groups and treated with vehicle or the fluorinated pyrrolone 10 and the non-halogenated derivative 9. Though MAC 16 tumours grew robustly from $100 \mathrm{~mm}^{3}$ to over $1500 \mathrm{~mm}^{3}$ within 2-3 weeks, the animals treated with both agents tumours grew slower. Both pyrrolones inhibited the tumour growth significantly from the day treatment was initiated and maintained tumour inhibitory activity until sacrifice. At sacrifice, interestingly in some animals growths was not only inhibited, but tumours shrinked after reaching a maximum volume. Most interestingly, while MAC 16 tumours in the vehicle-treated group metastasized to lungs, tumours in drugtreated groups did not metastasize to lungs.

Cholecystokinin is known to mediate cancer progression and metastasis, which were antagonised by sufficient concentrations of devazepide. ${ }^{27}$ 
One animal in vehicle-treated group died during the course of the study, which is typical for MAC 16 induced cancer, showing the lethality of this selected cancer model (Figure 8).

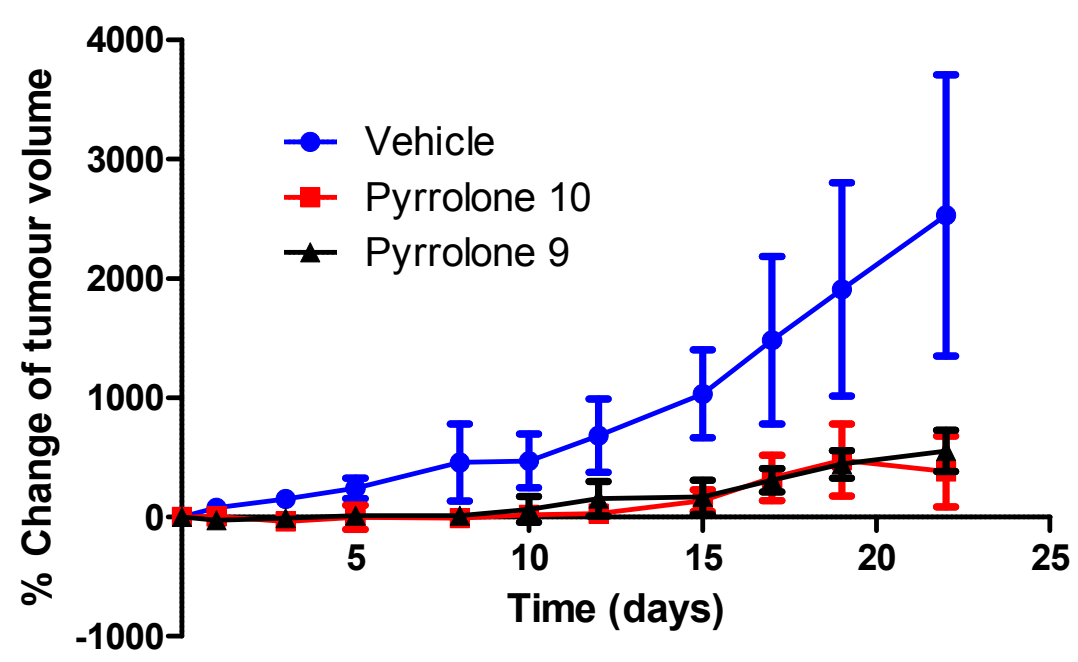

Fig. 8 Effect of pyrrolone 9 and 10 on MAC 16 colon cancer tumour growth.

Colon cancer is generally linked with the $\mathrm{CCK}_{1}$ receptor and only under certain conditions it is associated with the $\mathrm{CCK}_{2}$ receptor. ${ }^{28}$ Gastric cancer is correlated with the $\mathrm{CCK}_{2}$ receptor / gastrin receptor and in the human gastric cancer cell line HT-29, gastrin-17 stimulated growths and theses effects were abolished by $\mathrm{CCK}_{2}$ antagonists such as L-365,260. In detail Colucci tested only one $1 \mathrm{nM}$ concentration of devazepide, which stimulated growths in the study and by our own observations. Low nanomolar devazepide concentrations occur in vitro a CCK agonistic effect and this may explain why devazepide showed no significant effect in cancer previously. ${ }^{12}$

Overall for the MAC 16 cell line proliferation was blocked in vitro and in vivo by our pyrrolone based CCK antagonists. Here, the link $\mathrm{CCK}_{1}$ receptor and colon cancer was confirmed experimentally.

\section{MIAPACA tumour xenograft study}

MIAPACA tumours developed quickly after implantation and grew modestly, though not as robustly as MAC 16 tumours. Once the tumours reached $100 \mathrm{~mm}^{3}$, the animals were divided into various treatment groups and were treated with vehicle or respective 
drugs. Though vehicle-treated MIAPACA tumours grew from $100 \mathrm{~mm}^{3}$ to over 750 $\mathrm{mm}^{3}$ within 3 weeks, pyrrolone 9 and 10 - treated tumours grew slower.

Both agents inhibited tumour growth significantly from the day treatment was initiated and maintained the growth inhibitory properties until sacrifice (Fig. 9).

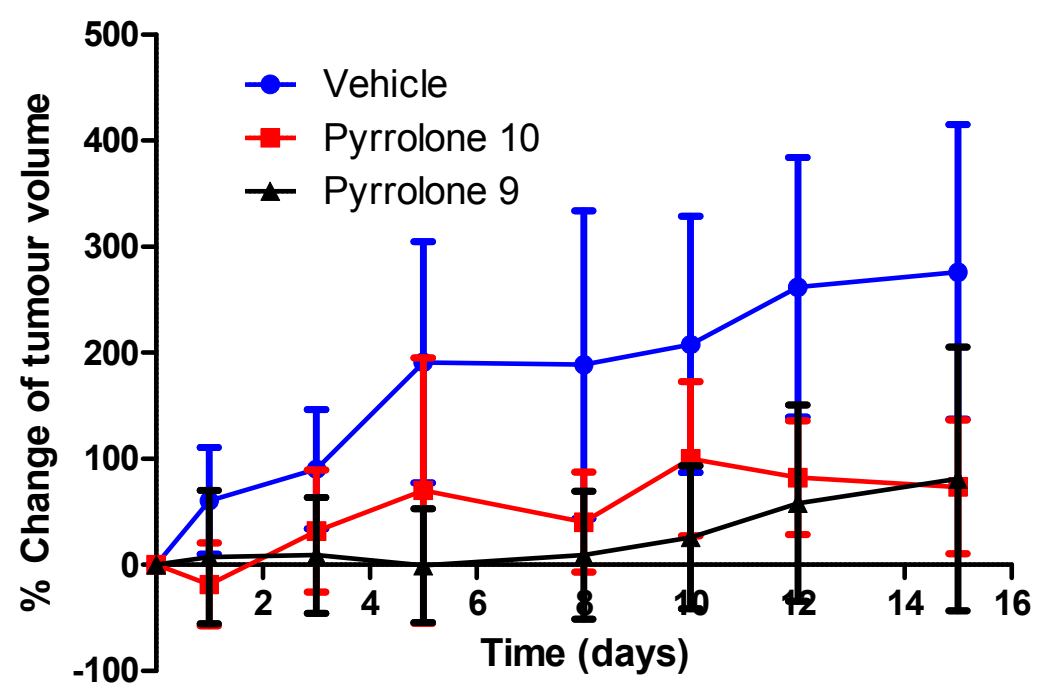

Fig. 9 Effect of pyrrolone 9 and 10 on MIAPACA pancreatic cancer tumour growth.

Overall, it was clearly shown, that colon and pancreatic cancers response to $\mathrm{CCK}_{1}$ antagonists and not $\mathrm{CCK}_{2}$ antagonists. ${ }^{29} \mathrm{We}$ agree, it is unlikely that, gastrin is more important in pancreatic cancer than cholecystokinin. It may be wise to say, that it is pancreozymin, via the pancreatic cholecystokinin receptor, that promotes cancer $\left(\mathrm{CCK}_{1 \mathrm{~b}}=\right.$ pancreozymin receptor and not $\mathrm{CCK}_{1 \mathrm{a}}$ cholecystokinin receptor $)$ or possibly the CCK-C receptor. Smith clearly stated the role of the CCK-C receptor in pancreatic cancer $^{30}$ and reviewed the cholecystokinin receptor as molecular target in treating pancreatic cancer. ${ }^{31}$ If it is the $\mathrm{CCK}-\mathrm{C}$ receptor, then according to recent nomenclature -the $\mathrm{CCK}_{3}$ receptor- would be the cancer target and molecular modelling based on the whole receptor, generated by homology modelling would be the starting point for further optimisation towards the $\mathrm{CCK}_{3}$ receptor. This would be advantageous as the $\mathrm{CCK}_{1}$ receptor is required for the physiological role of cholecystokinin. Blocking of 
the contractions of the gall bladder leads to gallstones in the long term and reductions of bile flow will result generally in liver toxicity.

\section{Conclusions}

This novel arylated hydroxyl-pyrrolone template was synthesised in only 2 synthetic steps in high overall yields from readily available starting material.

For the potent $\mathrm{CCK}_{1}$ ligands, a full non-competitive, possible irreversible CCK antagonism was confirmed classically, using isolated tissue preparations, which is ideal for an antineoplastic agent. For this novel template, it was found, that CCK antagonism translated into anti-cancer activity within the GI system and the known CNS activity of CCK antagonists may be of additional therapeutic benefit in treating cancer-associated diseases.

The isobutyl series stopped the growths of colon- and pancreatic cancer models and a full pre-clinical development programme was launched for the fluorinated pyrrolone 10. The new chemical entity PNB-028 progressed into late stage pre-clinical development for the treatment of human pancreatic and colon cancer.

All experiments were performed in compliance with the relevant laws and institutional guidelines.

The xenograft studies (RD-09/102014-4482403) in mice were performed and approved by the bioethics committee at the University of Tennessee Health Science Center, Cancer Research Building 19, Manassas, Memphis, TN 38103 and it was performed from May 2014 - July 2014 .

No human subjects were involved in this study.

The study was sponsored by PNB Vesper Life Sciences.

\section{References}

1 I. M. McDonald, Exp. Opin. Ther. Patents., 2001, 11, 445.

2 M. G. Bock, R. M. DiPardo, E. C. Mellin and N. C. Newton, J. Med. Chem., 1994, 37, 722.

3 E. Jorpes and V. Mutt, Acta Physiologica Scandinavica, 1966, 66, 196.

4 J. Bradwejn, D. Koszycki and G. Meterissian, Can. J. Psychiatry, 1990, 35, 83.

5 E. Lattmann and P. Arayarat, KKU. Sci. J., 2003, 31, 178. 
6 C. T. Dourish and S. Ravard, Trends Pharmacol. Sci., 1990, 11, 271.

7 K. Rasmussen, J. F. Czachura, M. E. Stockton and J. J. Howbert, J. Pharmacol. Exp. Ther., 1993, 264, 480.

8 C. T. Dourish, W. Rycroft and S. D. Iversen, Science, 1989, 245, 1509.

9 B. K. Trivedi, Curr. Med. Chem., 1994, 1, 313.

10 E. Lattmann, D. C. Billington, D. R. Poyner, S. B. Howitt and M. Offel, Drug Des. Discov., 2001, 17, 219.

11 B. E. Evans, K. E. Rittle, M. G. Bock, R. M. DiPardo, R. M. Freidinger, W. L. Whitter, G. F. Lundell, D. F. Veber, P. S. Anderson, R. S. Chang and D. J. Cerino, J. Med. Chem., 1988, 31, 2235.

12 J.L. Abbruzzese, C.F. Gholson, K. Daugherty, E. Larson, R. DuBrow, R. Berlin, B. Levin, Pancreas, 1992, 7, 165.

13 Y. Orikawa, H. Kato, K. Seto, N. Kobayashi, K. Yoshinaga, H. Hamano, Y. Hori, Mol. Pain, 2010, 6, 1744.

14 T. Meyer, M. E. Caplin, D. H. Palmer, J. W. Valle, M. Larvin, J. S. Waters, F. Coxon, I. Borbath, M. Peeters, E. Nagano and H. Kato, Eur. J. Cancer., 2010, 46, 526.

15 F. Makovec, R. Chistè, M. Bani, M. A. Pacini, I. Setnikar and L. A. Rovati, Arzneim.Forsch. / Drug Res., 1985, 35, 1048.

16 M. Offel, P. Lattmann, H. Singh, D. C. Billington, Y. Bunprakob, J. Sattayasai and E. Lattmann, Archiv der Pharmazie / Chemistry in Life Science, 2006, 339, 163.

17 E. Lattmann, H. Singh, J. Boonprakob, P. Lattmann and J. Sattayasai, J. Pharm. Pharm., 2006, 58, 1.

18 E. Lattmann, J. Sattayasai, J. Boonprakob, P. Lattmann and H. Singh, Arzneim.Forsch. / Drug Research, 2005, 55, 251.

19E. Lattmann, J. Sattayasai, Y. Boonprakob, H. Singh, P. Lattmann and S. Dunn, Drug Discov. Ther., 2008, 2, 156.

20 E. Lattmann, D. C. Billington, D. R. Poyner, P. Arayarat, S. B. Howitt, S. Lawrence and M. Offel, Drug Des. Discov., 2002, 18, 9.

21 E. Lattmann, J. Sattayasai, D. C. Billington, D. R. Poyner, P. Puapairoj, S. Tiamkao, W. Airarat, H. Singh and M. Offel, J. Pharm. Pharm., 2002, 54, 827.

22 E. Lattmann, P. Lattmann, H. Singh. (Aston University) WO2004106315A3. 2004. 
23 E. Lattmann, W. O. Ayuko, D. Kinchinaton, C. A. Langley, L. Karimi, H. Singh and M. J. Tisdale, J. Pharm. Pharm., 2003, 55, 1259.

24 R. Jamshidipour, E. B. Pinho, D. K. Hom and S. B. Howell, Cancer Chemother. Pharmacol., 1994, 34, 484.

25 J. C. Reubi, J. C. Schaer and B. Waser, Cancer Research, 1997, 57, 1377.

26E. Oikonomou, M. Buchfelder and E. F. Adams, Neuropeptides, 2008, 42, 255.

27 G. L. Matters, T. K. Cooper, C. O. McGovern, E. L. Gilius, J. Liao, B. M. Barth, M. Kester and J. P. Smith, Dig. Dis. Sci., 2014, 59, 1180.

28 R. Colucci, C. Blandizzi, M. Tanini, C. Vassalle, M. C. Breschi and M. Del Tacca, Br. J. Pharmacol., 2005, 144, 338.

29 G. L. Matters, C. McGovern, J. F. Harms, K. Markovic, K. Anson, C. Jayakumar, M. Martenis, C. Awad and J. P. Smith, Int. J. Oncol., 2011, 38, 593.

30 J. P. Smith, W. B. Stanley, M. F. Verderame and I. S. Zagon, Pancreas, 2004, 29, 271.

31 J. P. Smith and T. E. Solomon, Am. J. Physiol. Gastrointest. Liver. Physiol., 2014, 306, G91. 